\title{
TELAAH YURIDIS TERHADAP IMPLEMENTASI PRINSIP KEHATI-HATIAN BANK DALAM AKTIVITAS PERBANKAN INDONESIA
}

\author{
Lastuti Abubakar \\ Tri Handayani \\ Fakultas Hukum Universitas Padjadjaran \\ E-mail: lastuti62abubakar@gmail.com
}

\begin{abstract}
The main principle in banking activities is the prudential banking principle, which is regulated by Act No. 10/1998 on Amendment of Act No. 7/1992 concerning Banking as well as in Law No. 21/2008 concerning Sharia Banking. This prudential banking principle in practice is often normally interpreted, i.e only related to the provision of bank credit, or sometimes misinterpreted, resulting in a misperception of how and when this principle is applied in banking activities. This research uses the normative juridical approach with analytical descriptive research specification. Data were analyzed by qualitative juridical. Based on the research result, prudential banking principle must be applied starting from an institutional level, banking process, and services, including in banking credit. Banks are required to ensure compliance with regulations, including standard operating procedures issued by banks.
\end{abstract}

\section{Kata Kunci: Regulasi Perbankan, Prinsip Kehati-Hatian Bank, Aktivitas Perbankan}

\section{A. Latar Belakang}

Perkembangan regulasi perbankan Indonesia berkembang sangat pesat dari waktu ke waktu. Perubahan tatanan regulasi perbankan ini antara lain dipengaruhi oleh perkembangan jasa keuangan dan perbankan global serta munculnya beragam produk perbankan dan layanan jasa perbankan yang baru. Salah satu perubahan signifikan dalam regulasi perbankan Indonesia adalah terjadinya dualisme hukum perbankan, dengan diberlakunya Undang-undang Nomor 21 Tahun 2008 tentang Perbankan Syariah (UU Perbankan Syariah) yang berdampingan dengan Undang-undang Nomor 10 Tahun 1998 tentang Perubahan Undang-undang Nomor 7 Tahun 1992 tentang Perbankan (UU Perbankan). 
Hadirnya UU Perbankan Syariah, memberikan landasan hukum yang semakin kokoh bagi keberadaan aktivitas perbankan berdasarkan prinsip syariah. Dampak positifnya, alternatif pembiayaan dan investasi bagi masyarakat menjadi semakin beragam. Masyarakat Indonesia yang mayoritas muslim mempunyai alternatif untuk memperoleh pembiayaan dan investasi yang sesuai dengan prinsip syariah, khususnya terhindar dari larangan riba', maysir dan gharar, yang dalam aktivitas konvensional lazim digunakan baik dalam pemberian kredit berbasis bunga, dan produk yang bersifat spekulatif, yang seringkali dirasakan menimbulkan ketidakadilan.

Presiden Obasanjo dari Nigeria dalam pertemuan G-8 di Okinawa pada tahun 2000 memberikan pernyataan bahwa "if you ask me what is the worst thing in the world, I will say it compound interest", bahwa hal terburuk di dunia adalah bunga berbunga. Hal ini akibat utang Nigeria yang semula $\$ 5$ milyar pada tahun 1985-1986 menjadi \$ 28 milyar dalam kurun waktu 14 tahun yang timbul akibat bunga berbunga dari para kreditor (Ethica Institute, 2017: 24). Di sisi lain, perbankan syariah berkembang lambat, walaupun memperlihatkan grafik yang meningkat.

Beberapa isu strategis dalam pengembangan perbankan syariah di Indonesia adalah produk yang tidak variatif dan pelayanan yang belum sesuai dengan ekspektasi masyarakat; kuantitas dan kualitas sumber daya manusia yang belum memadai; pemahaman dan kesadaran masyarakat yang masih rendah sehingga menimbulkan mispersepsi masyarakat berkaitan dengan istilah, akad dan produk; termasuk persepsi bahwa perbankan syariah berbiaya mahal, serta pengaturan dan pengawasan yang belum optimal. Hal ini dapat diatasi dengan penerapan tata kelola yang baik pada perbankan syariah sebagai penjabaran prinsip kehati-hatian, yang bertumpu pada 5 pilar, yaitu: transparency, accountability, responsibility, independency dan fairness.

Selain itu, pengaruh perkembangan regional dan global berdampak antara lain pada keikutsertaan otoritas perbankan dalam organisasi perbankan dunia seperti International Organization on Securites Commission (IOSCO) dan Financial Stability Board (FSB), yang membuat sektor keuangan dan perbankan 
Indonesia memiliki standar internasional dan kompetitif. Pada tahun 2020, sebagai tindak lanjut dari kesepakatan Asean Economic Community (Masyarakat Ekonomi Asean), perbankan Indonesia harus sudah mengimplementasikan kesepakatan Asean Banking Integration Framework (ABIF) berdasarkan prinsip resiprokal dan non diskriminasi.

ABIF memberikan peluang bagi bank-bank ASEAN untuk masuk ke pasar wilayah negar-negara ASEAN (Tri Handayani \& Lastuti Abubakar, 2016: 144). Hal ini tentu memerlukan kesiapan infrastruktur hukum dan sumber daya manusia agar dapat memanfaatkan peluang seoptimal mungkin. Keikutsertaan Indonesia dalam kesepakatan ABIF tentunya dengan mempertimbangkan kepentingan ekonomi nasional, sehingga diperlukan model kesepakatan antar negara yang dibuat secara tepat dengan memperhatikan prinsip kehati-hatian bank.

Perkembangan produk dan layanan perbankan pun berkembang sejalan dengan kebutuhan dalam praktik, terutama untuk memenuhi kebutuhan ekonomi global. Perbankan yang fungsi utamanya sebagai intermediary, yaitu menghimpun dana dan menyalurkannya kepada pihak ketiga, semakin banyak menawarkan jasa berbasis komisi (fee based income). Hal ini menuntut pembaruan regulasi yang cepat, dan untuk mengantisipasi perubahan yang pesat tersebut, otoritas perbankan menerbitkan aturan, baik dalam bentuk Peraturan Otoritas Jasa Keuangan (POJK) maupun Peraturan Bank Indonesia (PBI). Perkembangan produk dan layanan jasa perbankan ini, tidak hanya berkontribusi terhadap perkembangan transaksi, tetapi banyak mengembangkan bidang hukum lain, seperti hukum kebendaan dan hukum surat berharga, serta aspek hukum teknologi informasi yang masih memerlukan sosialisasi, baik di internal perbankan maupun masyarakat pengguna jasa perbankan

Beberapa layanan jasa perbankan yang berkontribusi bagi perkembangan hukum perjanjian antara lain transaksi lindung nilai (hedging) yang digunakan oleh para pelaku usaha, khususnya importir untuk melakukan proteksi terhadap nilai mata uang terhadap perubahan kurs valuta asing (Lastuti Abubakar \& Tri Handayani, 2016). Selain itu, Bank dimungkinkan untuk menawarkan jasa sebagai trustee guna menarik dana-dana di dalam negeri yang biasanya disimpan 
di bank trust atau trust company di luar negeri untuk dikelola dan dioptimalkan dalam menggerakkan ekonomi nasional. Kegiatan trust ini merupakan jenis transaksi yang berkembang dalam praktik perbankan yang masih menyisakan beberapa isu hukum dalam implementasinya. Salah satu isu hukum yang mengemuka adalah dual ownership terhadap aset trust yang tidak dikenal dalam sistem hukum kebendaan Indonesia (Tri Handayani \& Lastuti Abubakar, 2014). Selain itu, perbankan nasional mulai banyak yang mengembangkan jasa yang berkaitan dengan aktivitas di pasar modal seperti kegiatan Wali Amanat dan Bank Kustodian.

Tuntutan ekonomi global, khususnya sejak krisis keuangan global men dorong perbankan mengembangkan jenis-jenis surat berharga baru, seperti assets backed securities atau collateral debt obligation (CDO) melalui proses sekuritisasi (Olivier Butsbach \& Kurt von Mettenheim, 2014: 1); atau derivatif lainnya yang diturunkan dari surat berharga asal nya. Transaksi derivatif dalam perbankan banyak digunakan dalam kaitannya dengan fungsi lindung nilai (hedging), antara lain forwards dan options.

Perkembangan surat berharga dalam aktivitas keuangan dan perbankan ini tentu memerlukan kajian lebih lanjut dari aspek hukum kebendaan Indonesia yang menganut sistem tertutup (Lastuti Abubakar, 2010). Melihat perkembangan layanan dan produk perbankan sebagaimana diuraikan di atas, dapat dibayangkan bahwa aktivitas perbankan mempunyai andil besar dalam pembaruan hukum ekonomi Indonesia.

Dari sisi penggunaan teknologi informasi, layanan jasa perbankan berkembang dengan ditawarkannya internet banking dan sistem pembayaran dan penyelesaian transaksi berupa Bank Indonesia Real Time Gross Settlement (BIRTGS) yaitu sistem transfer dana elektronik yang penyelesaiannya dilakukan dalam waktu seketika, yang memberikan banyak manfaat. Sistem BI-RTGS ini selain memberikan kepastian penyelesaian (settlement finality), juga menjadi sarana transfer dana antar bank yang efisien, handal dan aman. Selain BI-RTGS, diatur juga tentang Sistem Kliring Nasiona Bank Indonesia (SKNBI), yaitu sistem transfer dana elektronik yang meliputi kliring debet dan kliring kredit yang 
penyelesaian transaksinya dilakukan secara nasional. Perkembangan sistem pembayaran ini berpengaruh terhadap kepastian dan perlindungan hukum bagi transaksi nasabah. Selain itu, tercipta sistem pembayaran yang efisien dan teratur, sedangkan perkembangan teknologi telah menciptakan layanan perbankan dapat menjangkau di seluruh wilayah tanpa perlu membuka cabang (branchless banking) yang semakin memudahkan nasabah bertransaksi melalui smartphone (Brett King, 2014: 48). Di tataran perbankan global, berkembang apa yang dikenal sebagai private banking atau wealth management, sebagai bentuk bisnis bank lainnya yang didorong oleh beberapa kekuatan, yaitu: markets, regulatory, environtment, clients and competiton (Boris F.J. Collardi, 2012: 8).

Melihat pesatnya perkembangan produk dan layanan perbankan Indonesia yang semakin beragam dan kompleks, maka penerapan prinsip kehati-hatian dalam aktivitas perbankan menjadi semakin urgen dan relevan. Prinsip kehatihatian bank merupakan prinsip utama dalam aktivitas perbankan, tetapi dalam praktik seringkali dimaknai secara sempit, yaitu hanya dikaitkan dengan kewajiban bank untuk berhati-hati dalam melakukan analisa dalam pemberian kredit atau pembiayaan berdasarkan prinsip syariah. Oleh karena itu, tulisan ini bermaksud untuk menghasilkan kajian yuridis terhadap pemaknaan prinsip kehatihatian dan implementasinya dalam praktik, yang dalam pengalaman penulis beberapa kali diminta untuk memberikan keterangan ahli baik di kepolisian, kejaksaan maupun pengadilan, menunjukkan adanya perbedaan tafsiran terhadap prinsip kehati-hatian dalam UU Perbankan, khususnya menyangkut subjek atau organ bank yang bertanggungjawab untuk memastikan prinsip ini telah diterapkan secara baik. UU Perbankan dan UU Perbankan Syariah tidak memberikan definisi yang eksplisit tentang apa yang dimaksud dengan prinsip kehati-hatian, tetapi dapat dilihat dalam berdasarkan penafsiran sistematis, yaitu dengan mengaitkan satu pasal dengan pasal-pasal yang lain, penulis dapat menyimpulkan bahwa prinsip kehati-hatian bank berkaitan erat dengan kepatuhan bank pada seluruh peraturan perundang-undangan yang berlaku bagi bank, baik secara kelembagaan, proses dan produk. 
Kepatuhan terhadap seluruh peraturan perundang-undangan sangat penting, sehingga dalam struktur organisasi perbankan, khususnya bank umum, baik konvensional dan syariah wajib memiliki Direktur yang membawahi Fungsi Kepatuhan Bank dan Satuan Kerja Kepatuhan. Pelaksanaan fungsi kepatuhan ini tidak terlepas dari kompleksitas kegiatan usaha bank yang semakin meningkat sejalan dengan perkembangan teknologi informasi, globalisasi dan intergrasi pasar keuangan, yang berdampak besar terhadap eksposur risiko yang dihadapi oleh bank, sehingga diperlukan upaya-upaya untuk memitigasi risiko kegiatan usaha bank. Alasan inilah yang mendorong Bank Indonesia menerbitkan PBI No.: 13/2/PBI/2011 tentang Pelaksanaan Fungsi Kepatuhan Bank Umum.

Berdasarkan Pasal 3 huruf c PBI ini, Fungsi Kepatuhan Bank antara lain tindakan untuk: "memastikan agar kebijakan, ketentuan, sistem, dan prosedur serta kegiatan usaha yang dilakukan oleh Bank telah sesuai dengan ketentuan Bank Indonesia dan peraturan perundang-undangan yang berlaku, termasuk prinsip syariah bagi Bank Umum Syariah dan Unit Usaha Syariah; dan memastikan kepatuhan Bank terhadap komitmen yang dibuat oleh Bank kepada Bank Indonesia dan/atau otoritas pengawas lain yang berwenang (dalam hal ini: OJK). Dalam pekembangannya, fungsi kepatuhan ini dimasukkan sebagai salah satu bagian dalam POJK No.: 55/POJK.03/2016 tentang Penerapan Tata Kelola Bagi Bank Umum, yang diwujudkan dalam penerapan fungsi kepatuhan, audit intern, dan audit ekstern.

Mengacu pada ke PBI dan POJK tersebut, maka implentasi prinsip kehatihatian bank pada intinya adalah kepatuhan terhadap seluruh ketentuan perundangundangan dalam aktivitas perbankan. Selain itu, terdapat perbedaan pandangan mengenai siapa yang seharusnya memikul beban untuk menerapkan prinsip kehati-hatian bank ini? Apabila melihat kepada PBI dan POJK, penulis sependapat dengan pandangan umum, bahwa Direksi lah yang pertama memikul kewajiban ini mengingat fungsi kepatuhan dilaksanakan oleh direksi.

Dalam beberapa kasus, subjek yang dapat dimintai pertanggungjawaban terhadap pelanggaran prinsip kehati-hatian ini ditafsirkan secara sempit, yakni kepada organ pengurus atau dewan direksi. Dalam kasus yang lain, pegawai bank 
yang diperintahkan, dapat dimintai pertangungjawaban, terutama apabila menyadari bahwa perintah tersebut bertentangan dengan peraturan perundangundangan. Permasalahan yang lebih kompleks berkenaan dengan pelanggaran prinisp kehati-hatian dalam aktivitas Bank berupa Badan Usaha Milik Negara, dimana acapkali terjadi perdebatan apakah kerugian bank yang timbul akibat pelanggaran prinsip kehati-hatian bank termasuk dalam tindak pidana perbankan atau masuk ke dalam ranah "kerugian negara", yang ditafsirkan dan dimasukkan ke dalam ranah tidak pidana korupsi.

Perbedaan penafsiran dan implementasi prinsip kehati-hatian ini menimbulkan konsekuensi yuridis yang cukup berat, mengingat pelanggaran prinsip kehati-hatian bank ini masuk ke dalam tindak pidana perbankan. Berdasarkan permasalahan-permasalahan yang telah diuraikan di atas, penelitian ini bertujuan untuk menghasilkan kajian bagaimana implementasi prinsip kehatihatian (prudencial banking principle) ini dalam aktivitas perbankan Indonesia, terutama mengenai pemaknaan prinsip kehati-hatian bank, organ bank yang dapat dimintai pertanggungjawaban atas pelanggaran prinsip kehati-hatian bank serta lingkup dari peraturan perundang-undangan yang dilanggar.

\section{B. Metode Penelitian}

Penelitian bersifat deskriptif analitis, yaitu membuat pencandraan secara sistematis, faktual dan akurat mengani fakta-fakta. Oleh karena itu penelitian ini sifatnya mengkaji dan memaparkan permasalahan aspek hukum yang berkaitan dengan implementasi prinsip kehati-hatian bank.

Metode pendekatan yang digunakan adalah pendekatan yuridis normatif, dengan menekankan pada kajian terhadap data sekunder, berupa bahan hukum primer, yaitu peraturan perundang-undangan, bahan hukum sekunder, baik jurnal maupun hasil penelitian sebelumnya dan bahan hukum tersier. Selanjutnya, data yang diperoleh, baik berupa data sekunder dianalis secara yuridis kualitatif. 


\section{Hasil Penelitian dan Analisis}

\section{Prinsip kehati-hatian bank (prudencial banking principle) sebagai prinsip utama dalam aktivitas perbankan}

Perbankan Indonesia mempunyai fungsi penting dalam pembangunan ekonomi. Selain fungsi utamanya sebagai intermediary, yang mempertemukan pemilik dana (surplus of fund) dengan pengguna dana (lack of fund), perbankan mempunyai peran strategis dalam mendorong perekonomian Indonesia, yaitu sebagai agent of development, agent of services dan agent of trust (Otoritas Jasa Keuangan, 2016: 6). Ketiga peran tersebut akan berjalan dengan baik, apabila fungsi intermediary bekerja secara optimal. Bank menjadi alternatif pembiayaan bagi dunia usaha dan berperan menggerakkan perekonomian dengan menggunakan dana yang dipercayakan masyarakat kepada bank. Itu sebabnya perbankan seringkali disebut sebagai urat nadi perekonomian, yang menggerakkan sektor rumah tangga, dunia usaha termasuk usaha mikro kecil. Semakin besar penyaluran pembiayaan pada sektor dunia usaha, pembangunan ekonomi akan semakin meningkat, termasuk pemerataan pendapatan melalui penyerapan tenaga kerja. Siklus inilah yang menempatkan bank sebagai agent of development.

Selain sebagai alternatif pembiayaan, perbankan khususnya perbankan syariah menawarkan alternatif investasi yang dapat mengotimalkan keuntungan dari dana yang dipercayakan pada bank. Oleh karena itu, bank harus dapat menjadi agent of trust, dipercaya baik oleh pemilik dana maupun oleh pengguna dana. Mengingat dana yang disalurkan oleh bank merupakan dana pihak ketiga, bank wajib berhati-hati dalam pengelolaannya. Itu sebabnya, bank wajib memperhatikan dan mengimplementasikan prinsip kehati-hatian bank, sebagai bentuk pertanggungjwaban bank pada pihak ketiga. Dalam praktik, prinsip ini dominan digunakan dalam pemberian kredit atau pembiayaan berdasarkan prinsip syariah. Hal ini dapat dilihat dari kewajiban Bank untuk melakukan analisis sebelum kredit atau pembiayaan berdasarkan prinsip syariah disalurkan.

Implementasi prinsip kehati-hatian dalam pemberian kredit atau pembiayaan bertujuan untuk menghindari terjadinya kredit atau pembiayaan yang macet, sehingga prinsip ini lebih banyak ditafsirkan sebagai cara bagi bank untuk 
menghindari kredit/pembiayaan bermasalah atau kredit macet. Kredit/pembiayaan bermasalah atau kredit macet menjadi hal yang wajib dihindari oleh Bank, mengingat salah satu ukuran dalam penentuan tingkat kesehatan Bank adalah tinggi rendahnya non performing loan (NPL) bank. Berdasarkan Pasal 2 Peraturan Bank Indonesia (PBI) No.: 13/1/PBI/2011 tentang Penilaian Tingkat Kesehatan Bank Umum, diatur bahwa: "Bank wajib memelihara dan/atau meningkatkan Tingkat Kesehatan Bank dengan menerapkan prinsip kehati-hatian dan manajemen risiko dalam melaksakan kegiatan usaha”.

Tanggung jawab untuk memelihara dan memantau Tingkat Kesehatan Bank serta mengambil langkah-langkah yang diperlukan untuk memelihara dan/atau meningkatkan Tingkat Kesehatan Bank dibebankan kepada Direksi dan Dewan Komisaris. Selanjutnya, Bank wajib melakukan penilaian tingkat kesehatan dengan menggunakan pendekatan risiko (risk based bank rating). Salah satu faktor yang dinilai adalah profil risiko, yang antara lain berupa risiko kredit, dengan ancaman penurunan tingkat kesehatan bank apabila bank melanggar kewajiban untuk melakukan penilaian tingkat kesehatan bank sebagaimana diatur dalam PBI No.: 13/1/PBI/2011 tentang Penilaian Tingkat Kesehatan Bank Umum.

Dalam pemberian kredit, berdasarkan Pasal 8 dan penjelasan Pasal 8 UU Perbankan, implementasi prinsip kehati-hatian ini diterjemahkan sebagai keyakinan bank berdasarkan analisis yang mendalam atas itikad baik dan kemampuan, serta kesanggupan nasabah debitur untuk melunasi utangnya atau mengembalikan pembiayaan sesuai perjanjian kredit. Kewajiban yang sama diatur dalam Pasal 23 UU Perbankan Syariah. Untuk memastikan bahwa prinsip kehatihatian tersebut dilaksanakan dengan baik, bank umum wajib memiliki dan menerapkan pedoman perkreditan dan pembiayaan berdasarkan prinsip syariah, sesuai dengan ketentuan yang ditetapkan oleh Bank Indonesia.

Keyakinan atas kemampuan dan kesanggupan nasabah merupakan faktor penting yang harus diperhatikan oleh bank. Selanjutnya, untuk memperoleh keyakinan, sebelum memberikan kredit atau pembiayaan, bank harus melakukan penilaian yang seksama terhadap watak (character); kemampuan (capacity); modal (capital); agunan (collateral); dan prospek usaha (condition of economic), 
yang lazim dikenal dengan the 5 C's analysis of credit. Dalam penjelasan Pasal 8 ditegaskan, bahwa agunan merupakan salah satu unsur dalam pemberian kredit, sehingga apabila berdasarkan unsur-unsur lain telah dapat diperoleh keyakinan atas kemampuan nasabah debitur mengembalikan utangnya, maka agunan hanya berupa barang, proyek, atau hak tagih yang dibiayai dengan kredit yang bersangkutan. Hal ini berarti agunan wajib adalah jaminan pokok. Dalam praktik, untuk meminimalkan risiko kredit macet, Bank menekankan pada ketersediaan agunan (collateral), baik jaminan pokok maupun jaminan tambahan.

\section{Pengaturan prinsip kehati-hatian bank (prudential banking principle)}

dalam regulasi perbankan.

Baik UU Perbankan maupun UU Perbankan Syariah mengatur tentang kewajian bank untuk menerapkan prinsip kehati-hatian bank. Berikut pengaturan prinsip kehati-hatian dalam UU Perbankan dan UU Perbankan Syariah.

Tabel 1:

\section{Pengaturan Prudential Banking Principle dalam} UU Perbankan \& UU Perbankan Syariah

\begin{tabular}{|c|c|c|c|}
\hline No. & UU Perbankan & UU Perbankan Syariah & Keterangan \\
\hline 1. & $\begin{array}{l}\text { Pasal 2: } \\
\text { Perbankan Indonesia } \\
\text { dalam melakukan } \\
\text { usahanya berasaskan } \\
\text { demokrasi ekonomi } \\
\text { dengan menggunakan } \\
\text { prinsip kehati-hatian }\end{array}$ & $\begin{array}{l}\text { Pasal 2: } \\
\text { Perbankan syariah dalam } \\
\text { melakukan kegiatan } \\
\text { usahanya berasaskan } \\
\text { prinsip syariah, demokrasi } \\
\text { ekonomi, dan prinsip } \\
\text { kehati-hatian. }\end{array}$ & $\begin{array}{l}\text { Ke dua Pasal menekankan } \\
\text { kata perbankan/perbankan } \\
\text { syariah yang lingkupnya } \\
\text { meliputi segala sesuatu } \\
\text { yang menyangkut tentang } \\
\text { bank, mencakup } \\
\text { kelembagaan, kegiatan } \\
\text { usaha, serta cara dan } \\
\text { proses dalam melakukan } \\
\text { kegiatan usahanya. }\end{array}$ \\
\hline 2. & $\begin{array}{l}\text { Pasal 8: } \\
\text { Bank wajib memiliki } \\
\text { keyakinan berdasarkan } \\
\text { the } 5 \text { C's analysis of } \\
\text { credit sebelum } \\
\text { memberikan kredit atau } \\
\text { pembiayaan }\end{array}$ & $\begin{array}{l}\text { Pasal 23: } \\
\text { Bank wajib mempunyai } \\
\text { keyakinan atas kemauan } \\
\text { dan kemampuan calon } \\
\text { nasabah untuk melunasi } \\
\text { seluruh kewajibannya } \\
\text { berdasarkan the } 5 \text { C's } \\
\text { analysis penerima } \\
\text { fasilitas. }\end{array}$ & $\begin{array}{l}\text { Pasal ini membedakan } \\
\text { jaminan secara ekonomi } \\
\text { dan jaminan secara } \\
\text { yuridis. Itikad baik dan } \\
\text { kesanggupan bank untuk } \\
\text { membayar merupakan } \\
\text { jaminan secara yuridis, } \\
\text { sementara agunan } \\
\text { (collateral) merupakan } \\
\text { jaminan secara ekonomi. }\end{array}$ \\
\hline
\end{tabular}


Lanjutan Tabel 1:

\begin{tabular}{|c|c|c|c|}
\hline No. & UU Perbankan & UU Perbankan Syariah & Keterangan \\
\hline 3. & $\begin{array}{l}\text { Pasal } 29 \text { ayat (2): } \\
\text { Bank wajib memelihara } \\
\text { tingkat kesehatan bank } \\
\text { sesuai ketentuan } \\
\text { kecukupan modal, } \\
\text { kualitas aset, kualitas } \\
\text { manajemen, likuiditas, } \\
\text { rentabilitas, solvabilitas, } \\
\text { dan aspek lain yang } \\
\text { berhubungan dengan } \\
\text { usaha bank, dan wajib } \\
\text { melakukan kegiatan usaha } \\
\text { sesuai dengan prinsip } \\
\text { kehati-hatian. }\end{array}$ & $\begin{array}{l}\text { Pasal 35: } \\
\text { Bank syariah/Unit Usaha } \\
\text { Syariah wajib } \\
\text { menerapkan prinsip } \\
\text { kehati-hatian }\end{array}$ & $\begin{array}{l}\text { Pasal ini menekankan } \\
\text { kewajiban bank untuk } \\
\text { memastikan terlaksananya } \\
\text { proses pengambilan } \\
\text { keputusan dalam } \\
\text { pengelolaan bank. }\end{array}$ \\
\hline 4. & $\begin{array}{l}\text { Pasal } 29 \text { ayat (3): } \\
\text { Dalam memberikan kredit } \\
\text { atau pembiayaan } \\
\text { berdasarkan prinsip } \\
\text { syariah dan melakukan } \\
\text { kegiatan usaha lainnya, } \\
\text { bank wajib menempuh } \\
\text { cara-cara yang tidak } \\
\text { merugikan bank dan } \\
\text { kepentingan nasabah yang } \\
\text { mempercayakan danaya } \\
\text { kepada nasabah. }\end{array}$ & $\begin{array}{l}\text { Pasal 36: } \\
\text { Bank Syariah/UUS wajib } \\
\text { menempuh cara-cara yang } \\
\text { tidak merugikan Bank } \\
\text { Syariah/UUS dan } \\
\text { kepentingan Nasabah } \\
\text { yang mempercayakan } \\
\text { dananya. }\end{array}$ & $\begin{array}{l}\text { Mengingat bank bekerja } \\
\text { dengan dana dari } \\
\text { masyarakat yang } \\
\text { disimpan berdasarkan } \\
\text { kepercayaan, maka bank } \\
\text { perlu menjaga kesehatan } \\
\text { dan menjaga fungsinya } \\
\text { sebagai agent of trust. }\end{array}$ \\
\hline 5. & $\begin{array}{l}\text { Pasal } 29 \text { ayat (4): } \\
\text { Untuk kepentingan } \\
\text { nasabah bank wajib } \\
\text { menyediakan informasi } \\
\text { mengenai kemungkinan } \\
\text { timbulnya risiko kerugian } \\
\text { sehubungan dengan } \\
\text { transaksi nasabah yang } \\
\text { dilakukan melalui bank. }\end{array}$ & $\begin{array}{l}\text { Pasal 39: } \\
\text { Bank syariah dan UUS } \\
\text { wajib menjelaskan kepada } \\
\text { nasabah mengenai } \\
\text { kemungkinan timbulnya } \\
\text { risiko kerugian } \\
\text { sehubungan dengan } \\
\text { transkasi nasabah yang } \\
\text { dilakukan melalui bank } \\
\text { syariah/atau UUS. }\end{array}$ & \\
\hline
\end{tabular}

Sumber: UU Perbankan dan UU Perbankan Syariah

Mengacu pada pengaturan tentang prinsip kehati-hatian bank (prudential banking principle) dalam UU Perbankan dan UU Perbankan Syariah, dapat 
disimpulkan bahwa implementasi prinsip kehati-hatian ini dapat dilihat dari beberapa aspek, yaitu :

a. Penerapan prinsip kehati-hatian oleh perbankan sebagai lembaga, yang meliputi kelembagaan bank, kegiatan usaha, serta cara dan proses dalam melaksanakan kegiatan usahanya. Hal ini bermakna bahwa kewajiban bank menerapkan prinsip kehati-hatian sudah melekat sejak bank itu didirikan. Contoh sederhana, misalnya Bank berbentuk Perseroan Terbatas, maka seluruh regulasi yang berlaku dalam pendirian Bank berbentuk Perseroan Terbatas harus diperhatikan. Selanjutnya prinsip kehati-hatian wajib diterapkan dalam proses dan cara yang tercermin dalam pedoman atau standard operating procedures yang dibuat oleh bank. Prinsip kehati-hatian di sini harus ditafsirkan sebagai ketaatan bank terhadap seluruh regulasi yang berlaku sejak Bank didirikan, beroperasi dan menjalankan kegiatan usahanya.

b. Penerapan prinsip kehati-hatian dalam pemberian kredit, yang tujuannya untuk menghindari kredit atau pembiayaan yang bermasalah atau macet. Penerapan prinsip kehati-hatian di sini lebih menekankan pada tujuan bank untuk memenuhi tingkat kesehatan bank yang disyaratkan. Implementasi prinsip kehati-hatian dalam pemberian kredit, menjelma dalam kewajiban bank untuk melakukan analisa yang mendalam terhadap watak, kemampuan, permodalan, agunan dan prospek usaha nasabah sebelum menyalurkan kredit atau pembiayaan berdasarkan prinsip syariah. Secara imlisit, penerapan prinsip kehati-hatian disini juga dimaknai berhati-hati dalam menentukan calon nasabah.

c. Penerapan prinsip kehati-hatian yang dibebankan pada organ bank itu sendiri untuk menghindari bank dari kerugian dan menjaga kepentingan nasabah yang mempercayakan dananya kepada bank. Dengan demikian, bank wajib menjamin bahwa setiap tindakan hukum yang dilakukan oleh bank mematuhi seluruh peraturan perundang-undangan yang berlaku (regulatory compliance).

Berdasarkan uraian mengenai lingkup penerapan prinsip kehati-hatian di atas, maka penerapan prinsip kehati-hatian memiliki cakupan yang luas, tidak hanya berkaitan dengan proses pemberian kredit atau pembiayaan berdasarkan 
prinsip syariah. Penerapan prinsip kehati-hatian ini berkaitan erat kelembagaan bank, sejak bank didirikan, beroperasi, menerbitkan produk dan melayani nasabah. Termasuk ke dalam pengertian kelembagaan bank adalah penerapan prinsip kehati-hatian dalam menentukan sumber daya manusia yang memiliki kompetensi.

Berkaitan dengan sumber daya manusia di bidang perbankan, Otoritas Jasa Keuangan (OJK) telah menerbitkan POJK No.: 27/POJK.03/2016 tentang Penilaian Kemampuan dan Kepatutan Bagi Pihak Utama Lembaga Jasa Keuangan. Berdasarkan Pasal 1 POJK ini, Lembaga Jasa Keuangan meliputi pula Bank. Pihak Utama dalam POJK adalah pihak yang memiliki, mengelola, mengawasi, dan/atau mempunyai pengaruh yang siginifikan pada Lembaga Jasa Keuangan. Khusus untuk Bank, yang dimaksudkan dengan Pihak Utama adalah Pemegang Saham Pengendali (PSP); Anggota Direksi; dan Anggota Dewan Komisaris.

Menurut pendapat penulis, uji kemampuan dan kepatutan terhadap Pemegang Saham Pengendali merupakan hal yang sepatutnya dilakukan, mengingat Pemegang Saham Pengendali dapat menentukan dan mengambil keputusan terhadap perbuatan-perbuatan hukum yang akan dilakukan oleh Bank, sementara Bank wajib dikelola dengan prinsip-prinsip pengelolaan perusahaan yang baik (good governance) mengingat Bank berkewajiban memberikan perlindungan bagi pemangku kepentingan, khususnya pemilik dana.

\section{Kewajiban perbankan untuk menerapkan prinsip kehati-hatian bank (prudencial banking principle)}

Persoalan berikutnya adalah siapa yang wajib melaksanakan prinsip kehati-hatian bank ini dalam aktivitas perbankan. Pertama, tentu perlu dilihat bentuk badan usaha bank. Berdasarkan Pasal 21 UU Perbankan, bentuk badan hukum Bank Umum dapat berupa Perusahaan Daerah; Perseroan Terbatas (PT); Koperasi atau bentuk lain yang ditetapkan dengan Peraturan Pemerintah. Lazimnya, Bank Umum mengambil bentuk PT, sehingga berlakulah Undangundang Nomor 40 Tahun 2007 tentang Perseroan Terbatas (UU PT) sebagai lex generalis. Berdasarkan Pasal 92 UU PT, kewajiban untuk memastikan kepatuhan 
terhadap regulasi, termasuk menerapkan prinsip kehati-hatian bank berada ditangan Direksi sebagai organ perseroan yang bertanggungjawab untuk menjalankan pengurusan Perseroan untuk kepentingan Perseroan sesuai dengan maksud dan tujuan Perseroan yang dipercayakan kepadanya berdasarkan prinsip fiduciary duty. Dalam hal Perseroan Terbatas tersebut memperoleh ijin sebagai Bank, maka dalam menjalankan pengurusan, Direksi Bank mengacu pada UU Perbankan sebagai lex specialis, dan seluruh ketentuan yang berlaku bagi Bank.

Berdasarkan UU Perbankan, penerapan prinsip kehati-hatian bank tidak hanya menjadi tanggung jawab Direksi, melainkan juga dibebankan kepada anggota Dewan Komisaris dan Pegawai Bank. Hal ini dapat disimpulkan dari Pasal 49 ayat (2) b, yang mengatur, bahwa:

Anggota Dewan Komisaris, Direksi atau pegawai Bank yang dengan sengaja tidak melaksanakan langkah-langkah yang diperlukan untuk memastikan ketaatan bank terhadap ketentuan dalam undang-undang perbankan dan ketentuan peraturan perundang-undangan lainnya yang berlaku bagi bank, diancam dengan pidana ..."

UU Perbankan tidak mengatur secara tegas definisi dan fungsi Dewan Komisaris dan Direksi. Pasal 1 Angka 22 huruf a UU Perbankan hanya menyebutkan bahwa Anggota Dewan Komisaris, Pengawas, Direksi atau kuasanya, pejabat, atau karyawan bank ini masuk ke dalam pengertian Pihak Terafiliasi. Artinya, selain Dewan Komisaris, Direksi, pejabat atau karyawan Bank, terdapat pihak-pihak yang masuk dalam pengertian Pihak Terafiliasi, seperti pihak yang memberikan jasanya kepada bank, antara lain akuntan publik, penilai, konsultan hukum dan konsultan lainnya, serta pihak yang menurut Bank Indonesia (sekarang OJK) turut serta mempengaruhi pengelolaan Bank, antara lain pemegang saham dan keluarganya, keluarga Komisaris, dan keluarga Direksi. Oleh karena itu, berlaku ketentuan dalam UU PT sebagai lex generalis yang mengatur tentang Perseroan Terbatas (PT). Berdasarkan Pasal 1 angka 6 UU PT, yang dimaksud dengan Dewan Komisaris adalah "Organ Perseroan yang bertugas melakukan pengawasan secara umum dan/atau khusus sesuai dengan anggaran dasar serta memberi nasihat kepada Direksi”. Selanjutnya berdasarkan Pasal 1 angka 5 UU PT, yang dimaksud dengan Direksi adalah “Organ Perseroan yang 
berwenang dan bertanggung jawab penuh atas pengurusan Perseroan untuk kepentingan Perseroan, sesuai dengan maksud dan tujuan Perseroan serta mewakili Perseroan, baik di dalam maupun di luar pengadilan sesuai dengan ketentuan Anggaran Dasar. Dengan demikian, dapat disimpulkan bahwa Dewan Komisaris dalam konteks perbankan adalah "Organ bank yang bertugas melakukan pengawasan secara umum dan atau khusus sesuai dengan anggaran dasar serta memberi nasihat kepada direksi dalam pengurusan bank yang bersangkutan”, sedangkan yang dimaksud dengan direksi adalah organ bank yang berwenang dan bertanggungjawab penuh atas pengurusan bank sesuai dengan maksud dan tujuan bank yang bersangkutan, serta mewakili bank, baik di dalam maupun di luar pengadilan sesuai dengan ketentuan Anggaran Dasar.

Mengacu pada ketentuan-ketentuan baik dalam UU PT maupun UU Perbankan, maka berlakulah prinsip tanggung jawab dalam badan hukum, yaitu ultra vires, dimana baik Dewan Komisaris maupun Direksi dapat dimintai tanggung jawab pribadi apabila melakukan perbuatan hukum di luar kewenangan yang diberikan oleh peraturan perundang-undangan dan Anggaran Dasar Perseroan.

Selanjutnya, pengertian pegawai bank dapat dilihat dalam penjelasan beberapa pasal. Berdasarkan penjelasan Pasal 47 ayat (2) UU Perbankan, yang dimaksud dengan pegawai bank adalah semua pejabat dan karyawan bank. Penjelasan Pasal 48 ayat (1) memberikan spesifikasi berkaitan dengan "kerahasiaan Bank", yaitu memberikan pengertian pegawai bank adalah "pejabat bank yang diberi wewenang dan tanggung jawab untuk melaksanakan tugas operasional bank, dan karyawan yang mempunyai akses terhadap informasi mengenai keadaan bank".

Penjelasan Pasal 49 ayat (1) dan ayat (2) juga memberikan pengertian pegawai bank adalah "semua pejabat dan karyawan bank". Demikian juga penjelasan Pasal 49 ayat 2 (b), memberikan pengertian pegawai bank adalah "pejabat bank yang mempunyai wewenang dan tanggung jawab tentang hal-hal yang berkaitan dengan usaha bank yang bersangkutan". Dapat disimpulkan secara umum bahwa pegawai bank adalah semua pejabat dan karyawan bank. 
Berdasarkan penjelasan Pasal 49 ayat (2) b, yang dimaksud dengan pegawai bank adalah pejabat bank yang mempunyai wewenang dan tanggung jawab tentang hal-hal yang berkaitan dengan usaha bank yang bersangkutan. Dengan demikian, kewajiban menerapkan prinsip kehati-hatian bank melekat pada dewan komisaris, direksi dan pejabat bank yang mempunyai wewenang dan tanggung jawab tentang hal-hal yang berkaitan dengan usaha bank yang bersangkutan. Dalam praktik, penulis menemukan kasus dimana pegawai bank melakukan pelanggaran prinsip kehati-hatian bank dengan alasan perintah Direksi dan yang bersangkutan tidak dapat menolak. Pada prinsipnya pegawai Bank wajib melaksanakan prinsip kehati-hatian sesuai dengan kewenangannya. Dalam hal pegawai Bank melakukan pelanggaran prinsip kehati-hatian, padahal yang bersangkutan mengetahui bahwa perbuatan tersebut salah, tentu alasan "atas perintah atasan" bukan merupakan alasan pembenar. Hal ini merupakan konsekuensi yuridis yang harus ditanggung oleh pegawai bank, tetapi tentu hal ini dapat menjadi bahan pertimbangan bagi pengambil keputusan, khususnya hakim dalam memutuskan dan menjatuhkan sanksi kepada pegawai bank.

\section{Lingkup peraturan perundang-undangan yang wajib ditaati oleh perbankan.}

Aspek hukum lainnya yang memerlukan telaahan dalam penerapan prinsip kehati-hatian bank adalah makna "tidak melaksanakan langkah-langkah yang diperlukan untuk memastikan ketaatan bank terhadap ketentuan dalam undangundang ini dan ketentuan peraturan perundang-undangan lainnya yang berlaku pada bank" sebagaimana diatur dalam Pasal 49 ayat (2) b UU Perbankan. Dalam praktik, pelanggaran prinsip kehati-hatian yang banyak dilakukan adalah tidak dilakukannya langkah-langkah atau prosedur pemberian kredit yang dituangkan dalam pedoman pemberian kredit atau Standard Operating Procedures (SOP) yang dibuat oleh bank sebagai pedoman bagi Bank dalam menjalankan aktivitasnya. Pertanyaan yang muncul adalah apakah SOP Bank itu dapat dikatakan sebagai bagian dari ketentuan perundang-undangan, sehingga pelanggaran atau penyimpangan terhadap SOP dianggap pelanggaran prinsip kehati-hatian. Penulis berpendapat bahwa SOP atau pedoman yang dibuat dan berlaku di internal 
perbankan merupakan bagian dari ketentuan perundang-undangan dan ketentuan lain yang berlaku, sehingga pelanggaran SOP merupakan bentuk pelanggaran prinsip kehati-hatian. Pendapat ini berlandaskan pada Pasal 8 ayat (2) dan Pasal 15 UU Perbankan.

Pasal 8 ayat (2) mengatur bahwa: "Bank Umum wajib memiliki dan menerapkan pedoman perkreditan dan pembiayaan berdasarkan prinsip syariah, sesuai dengan ketentuan yang ditetapkan oleh Bank Indonesia”. Selanjutnya, dalam penjelasan Pasal 8 Ayat (2) disebutkan tentang pokok-pokok ketentuan yang ditetapkan oleh Bank Indonesia memuat antara lain:

a. pemberian kredit atau pembiayaan syariah dibuat dalam bentuk perjanjian tertulis;

b. bank harus memiliki keyakinan atas kemampuan dan kesanggupan Nasabah debitur yang antara lain diperoleh dari penilaian yang seksama terhadap watak, kemampuan, modal, agunan, dan prospek usaha dari Nasabah Debitur;

c. kewajiban bank untuk menyusun dan menerapkan prosedur pemberian kredit atau pembiayaan berdasarkan prinsip syariah;

d. kewajiban bank untuk memberikan informasi yang jelas mengenai prosedur dan persyaratan kredit atas pembiayaan berdasarkan prinsip syariah;

e. larangan bank untuk memberikan kredit atau pembiayaan berdasarkan prinsip syariah dengan persyaratan yang berbeda kepada Nasabah Debitur dan atau pihak-pihak terafiliasi.

f. penyelesaian sengketa.

Berdasarkan pokok-pokok pedoman di atas, maka lazim dalam praktik, perjanjian kredit dibuat dalam bentuk tertulis dalam bentuk standar (perjanjian baku), dimana klausula-klausula dalam perjanjian kredit atau pembiayaan berdasarkan prinsip syariah ditentukan oleh salah satu Pihak, dalam hal ini Pihak Bank, dan walaupun ditentukan oleh salah satu pihak, tidak berarti Bank bebas menentukan klausula perjanjian kredit, karena perjanjian baku tetaplah perjanjian, yang tunduk pada ketentuan Buku II KUHPerdata tentang Perikatan, khususnya berkenaan dengan syarat sah perjanjian yang diattur dalam Pasal $1320 \mathrm{KUH}$ Perdata. Selain itu, Bank wajib menginformasikan secara jelas mengenai syarat dan prosedur dalam pemberian kredit atau pembiayaan berdasarkan prinsip syariah, sehingga kesepakatan yang dberikan oleh Nasabah Debitur terbebas dari paksaan dan kekhilafan. 
Berkaitan dengan penyelesaian sengketa, OJK telah menerbitkan POJK No.: 1/POJK/2014 tentang Lembaga Alternatif Penyelesaian Sengketa Sektor Jasa Keuangan (LAPS), dan untuk penyelesaian sengketa perbankan telah terbentuk Lembaga Alternatif Penyelesaian Sengketa Perbankan Indonesia (LAPSPI), yang didirikan oleh Asosiasi Perbankan yang independen guna menyelesaikan sengketa perbankan di luar pengadilan. Penyelesaian sengketa di luar pengadilan ini bertujuan untuk meningkatkan kepercayaan masyarakat terhadap dunia perbankan, sehingga dunia perbankan dapat tumbuh dengan stabil. Penyelesaian sengketa perbankan melalui alternatif penyelesaian sengketa di luar Pengadilan sejalan dengan karakteristik perbankan sebagai intermediary dan penggerak perekonomian yang bertumpu pada kepercayaan masyarakat. Penyelesaian sengketa perbankan harus memperhatikan beberapa hal, antara lain:

a. keberlangsungan usaha Bank, mengingat Bank mengelola dana masyarakat yang harus dipertanggungjawabkan, sehingga penyelesaian melalui Pengadilan bukanlah upaya yang tepat. Putusan Pengadilan memposisikan para pihak sebagai pihak yang menang atau kalah, yang akan berdampak terhadap kepercayaan masyarakat dan keberlangsungan usaha.

b. Bank tidak kehilangan momentum bisnis, untuk menghindari kredit macet atau penarikan dana secara besar-besaran yang berpotensi menyebabkan bank mengalami kesulitan likuiditas.

c. Sejalan dengan regulasi perbankan, yang mengatur tahapan dalam menyelesaikan permasahan dengan nasabah, dengan menyediakan pengaduan nasabah, memfasilitasi mediasi oleh otoritas dan penyelesaian dengan mekanisme lembaga Alternatif Penyelesaian Sengketa Perbankan Indonesia (LAPSPI).

Sebagai catatan, penyelesaian sengketa yang dimaksud adalah sengketa yang menimbulkan kerugian pada nasabah akibat hubungan hukum yang timbul dalam ranah hukum perdata, baik akibat pelanggaran perjanjian antara Bank dan Nasabah maupun perbuatan melawan hukum yang diatur dalam Pasal 1365 KUHPerdata.

\section{Pelanggaran prinsip kehati-hatian bank (prudential banking principle) sebagai tindak pidana perbankan (Tipibank)}

Telah diuraikan sebelumnya, bahwa prinsip kehati-hatian bank ini merupakan prinsip utama dalam aktivitas perbankan, yang pelanggarannya tidak hanya akan membahayakan perbankan itu sendiri, tetapi berpotensi menimbulkan risiko yang lebih besar yaitu runtuhnya kepercayaan masyarakat terhadap bank 
dan berdampak terhadap perekonomian nasional. Oleh karena itu, dapat dipahami mengapa UU Perbankan dan UU Perbankan Syariah menggolongkan pelanggaran terhadap prinsip kehati-hatian bank ini sebagai pelanggaran yang dikenai sanksi pidana atau lazim disebut tindak pidana perbankan.

Pasal 49 ayat (2) b UU Perbankan dan Pasal 63 ayat (2) b UU Perbankan Syariah mengatur sanksi yang sama bagi Dewan Komisaris, Direksi atau pegawai bank yang dengan sengaja tidak melaksanakan langkah-langkah yang diperlukan untuk memastikan ketaatan bank terhadap ketentuan dalam undang undang dan ketentuan perundang-undangan yang lain yang berlaku bagi bank, diancam dengan pidana penjara sekurang-kurangnya 3 (tiga) tahun dan paling lama 8 (delapan) tahun, serta denda sekurang-kurangnya Rp. 5.000.000.000,00 (lima miliar rupiah) dan paling banyak Rp.100.000.000.000,00 (seratus miliar rupiah). Dalam praktik, kasus pidana perbankan yang mendasarkan pada Pasal 49 ayat (2) relatif sering terjadi, seperti pemberian kredit yang tidak sesuai dengan pedoman atau SOP pemberian kredit, atau kredit diberikan tanpa memenuhi persyaratan dokumen-dokumen yang diwajibkan berdasarkan pedoman pemberian kredit. Meskipun UU Perbankan dan UU Perbankan syariah secara tegas mengklasifikasikan pelanggaran terhadap prinsip kehati-hatian sebagai tindak pidana perbankan, tetapi dalam tataran global berkembang pemikiran bahwa tindak pidana perbankan termasuk ke dalam lingkup kejahatan bisnis.

Romli Atmasasmita (2010: 76) perpendapat bahwa secara yuridis, kejahatan bisnis menunjukkan adanya dua sisi, yaitu sisi perdata dan sisi pidana. Kedua aspek ini mempunyai tujuan yang berbeda dan karakteristik yang bertentangan satu sama lain. Aspek hukum perdata lebih mementingkan perdamaian di antara para pihak, sehingga sifat regulasi lebih mengemuka, sedangkan aspek pidana lebih mementingkan perlindungan kepentingan umum atau masyarakat luas atau negara, sehingga sifat memaksa lebih mengemuka.

Model penyelesaian terhadap kejahatan bisnis, termasuk tindak pidana perbankan saat ini berkembang ke arah model penyelesaian sengketa di luar pengadilan (out of court system), yang oleh Romli Atmasasmita (2010: 189), disebut dengan model pendekatan restoratif (restorative approach) dan 
rehabilitatif (rehabilitative approach), sebagai suatu model yang dapat digunakan dalam penyelesaian dalam sistem hukum pidana. Pendekatan restoratif bertujuan untuk memulihkan keadaan yang bermasalah atau mengalami ketidakseimbangan menjadi tidak bermasalah atau harmoni. Model pendekatan ini sebenarnya sejalan dengan spirit dalam hukum adat yaitu memulihkan ketidakseimbangan dalam kosmos.

Penulis berpendapat bahwa pada prinsipnya pendekatan restoratif dapat diterapkan dalam penyelesaian tindak pidana perbankan secara selektif, mengingat pendekatan ini berakar dari pendekatan ekonomi yang lebih mengutamakan efisiensi, sehingga dikhawatirkan mengabaikan unsur keadilan yang melekat pada tujuan penegakan hukum. Selain itu, penyelesaian tindak pidana perbankan wajib memperhatikan peran Bank sebagai agent of trust, untuk tetap menjaga kepercayaan masyarakat.

\section{Simpulan dan Saran}

\section{Simpulan}

Berdasarkan uraian yang telah dipaparkan, dapat disimpulkan beberapa hal, sebagai berikut:

a. Prinsip kehati-hatian merupakan prinsip utama yang wajib diterapkan dalam aktivitas perbankan, baik secara kelembagaan, proses maupun layanan dan produk perbankan, terutama dalam menjalankan fungsi intermediary, yaitu menghimpun dan menyalurkan dana kepada pihak ketiga. Dengan demikian, pengertian prinsip kehati-hatian bank harus ditafsirkan secara tepat sesuai maksud undang-undang, kepatuhan terhadap seluruh ketentuan perundangundangan. Salah satu penerapan prinsip kehati-hatian bank yang diatur dalam UU Perbankan dan UU Perbankan Syariah adalah dalam mekanisme pemberian kredit atau pembiayaan syariah, yang mewajibkan bank untuk mempunyai keyakinan atas kemampuan dan itikad baik bank untuk membayar utang/menunaikan kewajibannya dalam pembiayaan syariah serta melakukan analisa yang mendalam terkait watak (character), kemampuan (capacity), 
permodalan (capital), jaminan (collateral) serta prospek usaha (conditon of economic) atau yang dikenal dengan the 5 C's analysis of credit.

b. Kewajiban untuk menerapkan prinsip kehati-hatian bukan hanya menjadi tanggung jawab Direksi Bank, tetapi juga menjadi kewajiban Dewan Direksi dan pejabat bank yang mempunyai wewenang dan tanggung jawab tentang hal-hal yang berkaitan dengan usaha bank yang bersangkutan.

c. Kepatuhan terhadap seluruh ketentuan perundang-undangan dan ketentuan lain dalam UU Perbankan dan UU Perbankan Syariah, mencakup segala peraturan yang berkaitan dengan aktivitas perbankan, termasuk pedoman atau Standard Operating Procedures (SOP) yang diterbitkan oleh Bank. Hal ini berdasarkan ketentuan dalam Pasal 8 ayat (2) dan Pasal 15 UU Perbankan, yang mewajibkan bank umum dan BPR memiliki pedoman kredit (SOP), sehingga SOP merupakan amanat undang-undang yang harus dipatuhi.

\section{Saran}

a. Perbankan perlu membuat pedoman atau SOP yang lebih komprehensif dan jelas mengenai implementasi prinsip kehati-hatian di internal Bank.

b. Perlu sosialisasi secara berkesinambungan di internal bank mengenai siapa yang wajib melaksanakan dan bertanggungjawab atas penerapan prinsip kehati-hatian. 


\section{DAFTAR PUSTAKA}

\section{Buku:}

Butzbach, Olivier \& Kurt von Mettenheim. 2014. Alternative Banking and Financial Crisis. London: Pickering \& Chatto..

Collardi, Boris F.J. 2014. Private Banking-Building a Culture of Excellence. Singapore: Wiley Finance.

Ethica Institute. 2017. Handbook Of Islamic Finance 2017 Edition. Dubai-United Arab Emirates: Ethica Institute of Islamic Finance.

King, Brett. 2014. Breaking Banks-The Innovators, Rogues, and Strategists Rebooting Banking. Singapore: Wiley.

Lastuti Abubakar. 2009. Transaski Derivatif di Indonesia-Tinjauan Hukum tentang Perdagangan Derivatif di Bursa Efek. Bandung: Book Terrace \& Library.

Otoritas Jasa Keuangan. 2016. Perbankan-Seri Literasi Keuangan Perguruan Tinggi, Jakarta: Otoritas Jasa Keuangan (OJK).

Romli Atmasasmita. 2010. Globalisasi Kejahatan Bisnis. Jakarta: Kencana.

\section{Jurnal:}

Lastuti Abubakar dan Tri Handayani. 2016. "Transaksi Lindung Nilai (Hedging) dalam Praktik Perbankan dan Implikasinya terhadap Pembaruan Hukum Kontrak Nasional”. Jurnal Rechtidee. Vol. 11. No. 1 Juni.

Tri Handayani \& Lastuti Abubakar. 2014. "Implikasi Kegiatan Penitipan dengan Pengelolaan (Trust) dalam Aktivitas Perbankan terhadap Pembaruan Hukum Perdata Indonesia". Jurnal Litigasi, Vol. 15 No. 2.

Tri Handayani \& Lastuti Abubakar. 2016. "Implikasi Kesepakatan Asean Banking Integraton Framework (ABIF) terhadap Pembaruan Hukum Perbankan Indonesia”. Jurnal Rechtidee, Vol. 11. No. 2. Desember.

\section{Peraturan Perundang-undangan:}

Republik Indonesia, Undang-undang Nomor 10 Tahun 1998 tentang Perubahan Undang-undang Republik Indonesia Nomor 7 Tahun 1992 tentang Perbankan.

Republik Indonesia, Undang-undang Nomor 40 Tahun 2007 tentang Perseroan Terbatas 
Republik Indonesia, Undang-undang Nomor 21 Tahun 2008 tentang Perbankan Syariah.

\section{Internet:}

Bank Indonesia. "Edukasi Sistem Pembayaran”. "http://www.bi.go.id/id/sistempembayaran/edukasi/Pages/edukasi_SIKILAT.aspx. Diakses tanggal 13 Mei 2017. Pukul 13.43 WIB.

Bank Indonesia. "Sistem Setelmen”. http://www.bi.go.id/en/sistem-pembayaran/ sistem-setelmen/bi-rtgs/bi-rtgs/Contents/Default.aspx. Diakses tanggal 13 Mei 2017. Pukul 13.45 WIB. 


\section{BIODATA PENULIS}

$\begin{array}{ll}\text { Nama } & \text { : Dr. Lastuti Abubakar, S.H., M.H } \\ \text { Pekerjaan } & \text { : Dosen } \\ \text { Jabatan } & :- \\ \text { Nomor HP } & : 08122150155 \\ \text { E-mail } & \text { : lastuti.abubakar@unpad.ac.id } \\ \text { Alamat Kantor } & \text { : Jl. Dipati Ukur No. 35, Bandung }\end{array}$

Nama : Tri Handayani, S.H., M.H

Pekerjaan : Dosen

Jabatan

Nomor HP : : 081313407048

E-mail $\quad$ : tri.handayani@unpad.ac.id

Alamat Kantor : Jl. Dipati Ukur No. 35, Bandung 